\title{
Who Wins \\ in \\ Conference Committee?
}

\author{
Replaces California Institute of \\ Technology Social Science Working \\ Paper \# 30
}

John FEREJohn

\begin{abstract}
$\mathrm{T}$
HERE IS NO AREA of congressional decision-making about which there is less academic consensus than there is about the conference committee. The major studies-by Fenno, ${ }^{1}$ Manley, ${ }^{2}$ Steiner, ${ }^{3}$ and Vogler ${ }^{4}$ - have come to disparate conclusions which, at least on the surface, seem difficult to reconcile with each other. Each of these studies poses the question, "Who wins in conference, the House or the Senate?" To settle the question, each develops his own measure of who wins. Briefly, Steiner found that in his sample of conference decisions, the House generally prevails. Fenno and Vogler each discovered a pattern of Senate dominance. Fenno worked only with appropriations conferences while Vogler assembled a much broader sample of legislative as well as appropriations conferences. Manley found that, among conferences between Ways and Means and the Senate Finance Committee, the Senate prevailed on certain issues (revenues, trade), while the House dominated on social security legislation.

For several reasons these findings should not be accepted as they

1 Richard Fermo, The Power of the Purse (Boston: Little-Brown, 1966).

2 John Manley, The Politics of Finance (Boston: Little-Brown, 1970).

${ }^{3}$ Gilbert Steiner, The Congressional Conference Committee (Urbana, University of Illinois Press, 1951 ).

${ }^{4}$ David Vogler, "Patterns of One House Dominance in Congressional Conference Committees," Midwestern Journal of Political Science 14 (1970), 303320.
\end{abstract}


stand. First, Fenno presents a wealth of evidence and personal observation which could lead one to believe that the House was the more potent force in conference. The House conferees are better prepared, better organized, and generally seem to care more about the legislation. Moreover, many of them, and their Senate counterparts, too, think they are relatively more successful in conference than the Senate. Manley discounts Fenno's interview evidence on this point as a bit tainted by a natural disposition of the House conferees to overestimate their effectiveness, but his observations, too, generally support the view that the House possesses the preponderance of advantages in the conference.

To be sure, Fenno and Manley each offer reasonable explanations for their findings. Fenno appealed to two closely related factors.

(1) The Senate conferees' goals were more congruent with the goals of other Senators than the goals of House conferees were with the goals of other House members.

(2) Many House members were more in sympathy with the Senate position than they were with the position of the House Appropriations Committee.

Manley suggested that the pattern of Senate dominance in certain areas may be attributable to the fact that the Senate position enjoys more support of the active lobbying groups than does the House position.

In this note I shall suggest a different explanation of Fenno's and Manley's results which seems to work well for a somewhat more restricted set of data than is found in the other studies. When applied to a broader set of data, such a theory may help resolve the paradoxical results of these earlier works.

The present study is based on the idea that the models used by other authors to analyze the conference implicitly postulate a kind of conflict between the House and Senate that seems uncharacteristic of such conference decision-making. The model introduced here is close in spirit to Manley's observation.

The overriding ethic of the Conference Committee is one of bargaining, giveand-take, compromise, horse-trading, conciliation, and malleability by all concerned . . . compromise is the candid rule of conference committees. Small wonder that each side claims victory, because almost everyone does winsomething, somehow, sometime. ${ }^{5}$

${ }^{5}$ Manley, Politics of Finance, 271. 
I shall attempt to demonstrate that recognition of the cooperative behavior between the House and Senate conferees can lead to a much different interpretation of data on conference decision-making.

\section{METHODS}

To study conference outcomes, each of the studies mentioned first identified the House and Senate positions on the bill (or in Manley's study, on sections of a bill). Then each found the conference position and determined whether it was "closer" to the House or Senate version. In most cases, these positions were measured in dollars, but various modifications were present in some of the studies. The basic idea behind this method is the assumption that each chamber employs its own judgment to determine just the sort of final legislation it would like to see. It then codifies this into its bill through its own internal decision procedures.

This assumption seems questionable on the basis of evidence presented in some of the studies being examined. Fenno gives evidence to suggest that the Senate bill may sometimes contain a bit larger appropriation than the Senate would like to see since they expect to have to accede somewhat to the House in the conference. By the same token, Senators seem to believe that the House bill is not an accurate record of what the House actually wants. "The dominant image which the Senate [Appropriations] Committee members have of the House is that the House deliberately reduces budget estimates below what it knows is reasonable in order to get the credit for economy action. ${ }^{6}$ These remarks indicate that the time sequencing of the decision-making processes induces the actors to make moves at various stages which are strategic rather than direct expressions of their real goals. Taking these strategic announcements at face value in computing a measure of House or Senate "dominance in conference" seems to be asking for trouble.

To avoid this pitfall, let us note that conferees might be supposed to make decisions in at least two distinct ways. The first model is based on the assumption that each chamber recommends the bill it would most like to see. The conferees then confront each other item by item and hammer out a report that strikes a balance between the two bills. One might expect that in such a process, a dominant mode of conflict resolution on bills characterized by dollar

${ }^{6}$ Fenno, Power of the Purse, 538. 
figures (like appropriations bills) would be "splitting the difference."

A second model of the conference asserts that each chamber is interested in different (though possibly overlapping) sections of the bill. In this case many of the changes made in one house might stand unmodified by the other, though the areas of overlapping interest would contain items about which the two chambers disagreed. The conferees would then just accept the recommendations of the House and Senate on the parts of the bill where only one of the two houses manifested interest. For those items where the chambers disagreed, a "split-the-difference" method of conciliation might be employed in the conference.

Decision-making on the appropriations bill containing the Army Corps of Engineers budget over a period from 1951 to 1967 offers an opportunity to examine decision-making procedures which might be consistent with either of the two proposed models. ${ }^{7}$ By the characterizations of the two models given here, the more the two chambers manifest interest in the same items of the bill, the more prevalent split-the-difference decision-making in conference should be. Figure 1 presents a measure of the overlap in manifested interest in the Corps of Engineers budget between the House and Senate and an indication of how frequently a split-the-difference

\footnotetext{
7 The statistical data in this study is from the following sources: U.S. Congress, House, House Appropriations Committee, Conference Reports of the Public Works Subcommittee for FY 1956 to FY 1968, 84th Cong., 1st sess. to 90th Cong., 1st sess. (Washington, D.C.: Govermment Printing Office). U.S. Congress, House, House Appropriations Committee, Public Works Subcommittee, Reports on Public Works Appropriations for FY 1956 to FY 1968, 84th Cong., 1st sess. to 90th Cong., 1st sess. (Washington, D.C.: Government Printing Office). U.S. Congress, Senate, Senate Appropriations Committee, Public Works Subcommittee, Reports on Public Works Appropriations for FY 1956 to FY 1968, 84th Cong., 1st sess. to 90th Cong., 1st sess. (Washington, D.C.: Government Printing Office). U.S. Congress, House, House Appropriations Committee, Reports, Civil Functions Appropriations for the Department of the Anny for FY 1952 to FY 1955, 81st Cong., lst sess. to 83rd Cong., 2nd sess. (Washington, D.C.: Government Printing Office). U.S. Congress, House, House Appropriations Committee Conference Reports, Civil Functions Appropriations for the Department of the Army for FY 1952 to FY 1955, 81st Cong., 1st sess. to 83rd Cong., 2nd sess. (Washington, D.C.: Government Printing Office). U.S. Congress, Senate, Senate Appropriations Committee, Reports Civil Functions Appropriations for the Department of the Army for FY 1952 to FY 1955, 81st Cong., 1st sess. to 83rd Cong., 2nd sess. (Washington, D.C.: Govemment Printing Office).
} 
Figure 1

OvEruapping INTEREST AND SPLITTXNG-THE-DIFFERENCE IN CONFERENCE

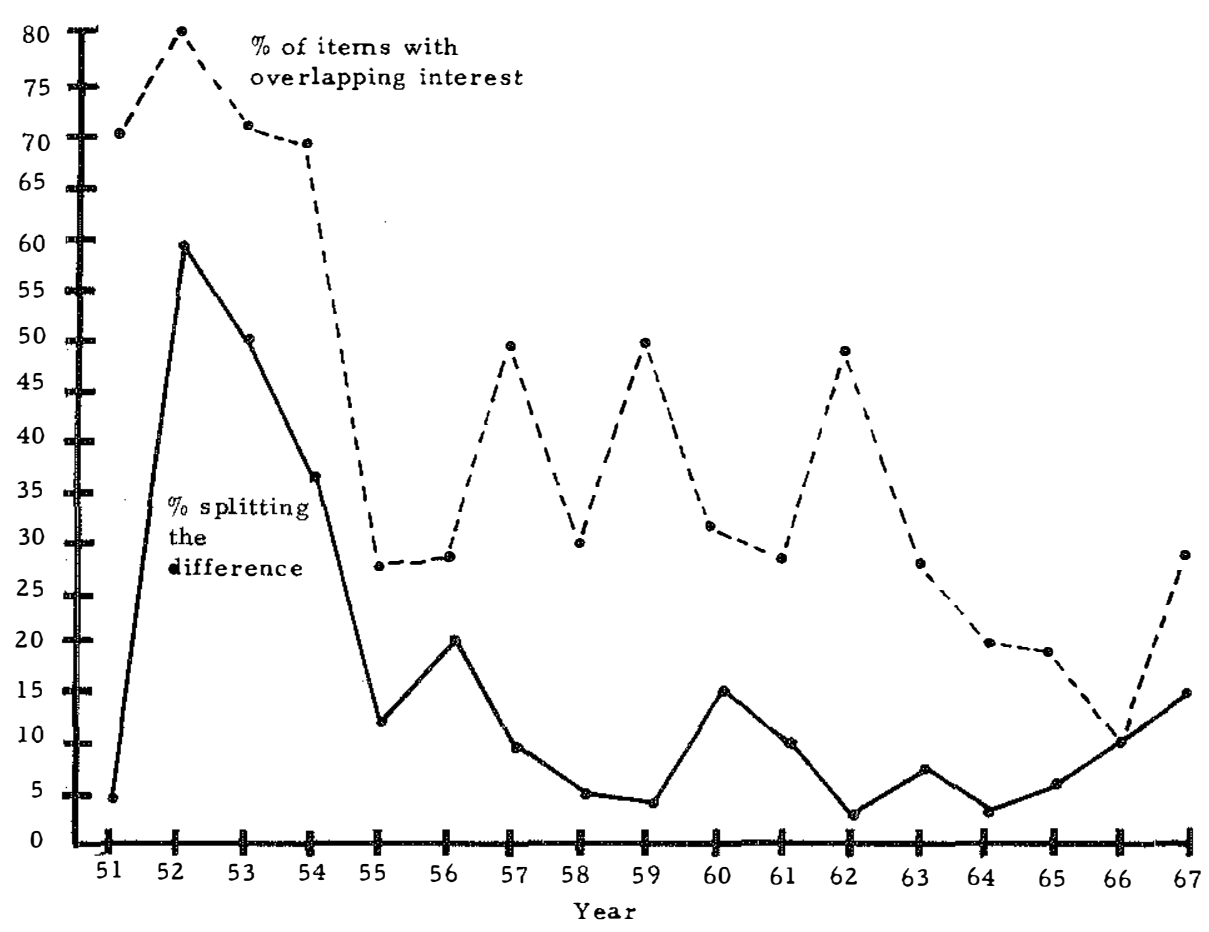


decision-making in conference should be. Figure 1 presents a measure of the overlap in manifested interest in the Corps of Engineers budget between the House and Senate and an indication of how frequently a split-the-difference procedure was employed by conferees. The overlap measure is simply the ratio of the number of projects that both chambers changed (i.e., the number of projects in which the House modified the budget figure and the Senate changed the House figure, or, in which the Senate changed the budget figure and the conference changed the Senate figure) over the total number of projects upon which either chamber modified the budget estimate. The split-the-difference measure is the ratio of the number of times the conferees chose a final figure on an item between the House and Senate figures over the total number of items in disagreement. The correlation between these two series was $.63(t=3.2)$. It's worth noticing for purposes of comparing the two models that there appears to have been a noticeable difference in both overlapping interest and split-the-difference decision-making between the 1951-1954 period and the 1955-1967 period.

In order to decide "who wins" in conference, it is necessary to introduce a definition of what it means to "win" in this situation. Not surprisingly, considering the already remarked tendency for the chambers to produce bills that are out of line with what each actually prefers, the notion of "who wins" depends on which theory of conference decision-making is accepted. But first, some assumptions are necessary about the actual desires of the House and Senate on the Corps budget:

(1) Both bodies are interested in adding certain projects to the President's budget.

(2) Only the House has any interest in cutting the budget. ${ }^{8}$

(3) The Senate acts an as "appeals-court" for agents who are dissatisfied with House or Budget Bureau decisions.

The House is successful in conference to the extent that it can get the new projects it puts into the budget approved in conference, sustain the cuts it makes in the President's budget, and restrains

${ }^{8}$ In principal there is no reason that the Senate might not take an interest in cutting appropriations after the House has completed its work. For reasons admirably summarized in Fenno's book, this behavior is extremely uncommon and so I choose not to complicate the model to include it as a possibility. One could modify the model to allow this sort of behavior, further complicating in the process the problem of deciding who wins in conference. 
the inclusion of new Senate projects. The Senate is successful in conference if it can keep its new projects in the conference report and successfully restore some of the House cuts in the budget. The relative success of the two bodies is therefore partly (not totally) in conflict. The question of "who wins" in this model translates into "which body does better in attaining its goals."

One of course must be prepared to accept the possibility of an ambiguous answer, since each body is presumed to have more than one goal and since those goals are not wholly in conflict. The House may retain most of its new starts in conference but not be able to sustain many budget cuts. The Senate may be relatively unsuccessful at retaining new starts but still be able to restore most budget cuts made in the House. In such a case, the question of who does better is basically unresolved. I am willing to accept such a possibility. After all, a single-valued measure of "dominance" may assure us of answering the "who wins" question as posed, but it may also lead us to produce a judgment where, in truth, no grounds for such a judgment exist.

\section{A MODEL}

In this section we present a simple model of decision-making in the House, Senate and conference committees on appropriations for the Corps of Engineers. The central idea is to show that once an explicit model of decision-making is introduced, a somewhat different interpretation of the data on conference outcomes than is proposed by previous authors becomes plausible. Once the model is set out it is possible to obtain estimates of its parameters in order to determine an answer to the question "who wins?"

Let $\mathrm{H}_{\mathrm{t}}$ be the total number of changes in the budget figure by the House. $\mathrm{H}_{\mathrm{t}}$ can be decomposed into the number of upward changes $\left(U_{t}{ }^{H}\right)$ and the number of downward changes $\left(D_{t}\right)$. The number of Senate changes in the budget request is composed of all the upward changes by the House $\left(\mathrm{U}_{\mathrm{t}}^{\mathrm{H}}\right)$, all the upward changes by the Senate $\left(U_{t} \mathbf{S}\right)$, plus the number of the downward changes by the House which the Senate did not restore $\left((1-a) D_{t}\right)$ where a is the proportion of downward changes by the House that the Senate restores. The number of disagreements between the bills is the sum

$$
\mathrm{U}_{\mathrm{t}} \mathrm{s}+\mathrm{aD}_{\mathrm{t}} \text {. }
$$

The conference, according to the proposed decision rule, accepts 
some proportion (b) of all the Senate changes and (let us say) one half of the real disagreements $\left(a_{t}\right)$. Thus, the conference outcome is

$$
\mathrm{bU}_{\mathrm{t}}^{\mathrm{s}}+\underset{2}{\frac{\mathrm{l}}{2} \mathrm{aD}_{\mathrm{t}}}
$$

and $b$ is very close to one, indicating that the House accepts nearly all the Senate's proposed upward changes just as the Senate accepted all the House's. With these parameter values the House would seem to be more influential than the Senate in conference if $\mathrm{b}$ is less than 1.0, but the Fenno-Vogler method of measuring victories would give

$$
\mathrm{bU}_{\mathrm{t}} \mathrm{s}+\frac{1}{2} \mathrm{aD}_{\mathrm{t}}
$$

Senate victories. In percentages the Senate success would be

$$
\frac{\mathrm{bU}_{\mathrm{t}}^{\mathrm{s}}+\frac{1}{2} \mathrm{aD}_{\mathrm{t}}}{\mathrm{U}_{\mathrm{t}} \mathrm{s}+\mathrm{aD}_{\mathrm{t}}}
$$

It may be enlightening to see how the enate success ratio behaves when certain plausible parameter and data values are chosen. For expositional purposes we give some reasonable estimates for each of these parameters:

$$
\begin{array}{ll}
\mathrm{U}_{\mathrm{t}} \mathrm{S}=40-100 & \begin{array}{l}
\text { approximate number of upward } \\
\text { change in the budget by the } \\
\text { Senate }
\end{array} \\
\mathrm{D}_{\mathrm{t}}=10-40 & \begin{array}{l}
\text { approximate number of downward } \\
\text { changes by the House }
\end{array} \\
\mathrm{a}=\frac{2}{3} & \begin{array}{l}
\text { proportion of Senate revisions of } \\
\text { House downward changes }
\end{array} \\
\mathrm{b}=.9 & \begin{array}{l}
\text { House acceptance of Senate up- } \\
\text { ward changes in conference }
\end{array}
\end{array}
$$

These ranges of estimates were obtained by consideration of the stage-by-stage budget data over the period under study. Under 
the model postulated here the estimates for Senate success ratio used by Fenno and Vogler range from .74 to .84 even though as the model is set up, the House is slightly more influential since it does not accept all of the upward changes the Senate recommends although the Senate accepts all the upward changes the House allows.

Casual observation indicated that the a parameter (the proportion of House deletions that the Senate restores) seemed quite stable, while the $b$ parameter (the proportion of Senate upward changes that the House accepts in conference) appears to vary a good deal from year to year. If one wants to explain the observed results of Fenno and Vogler-that the Senate wins 65 percent of the time-by use of this model it would be most plausible to permit $\mathrm{b}$ to vary while fixing a at its average level. It should be remembered that as b gets smaller the House is, in effect, getting more powerful. Estimates of $\mathrm{b}$ in the range .5 to .7 give outcomes of Senate "wins" around 65 percent of the time depending on $\mathrm{U}_{\mathrm{t}} \mathrm{S}$ and $D_{t}$ in each year. The "real" estimate of influence in this model is reflected in the parameter $b$ and in it the House is the more persuasive body since it retains all of the new starts it desires but only yields to the Senate on $100 \times \mathrm{b}$ percent of its starts.

The data utilized here is at the project level, unlike the data employed by Fenno and Vogler. The same model may work for bills rather than projects with little modification by allowing $\mathrm{U}^{\mathbf{H}}, \mathrm{U}^{\mathrm{S}}$, and $\mathrm{D}$ to refer to dollar amounts and leaving $\mathrm{a}$ and $\mathrm{b}$ with the same interpretation. The point is that the results obtained by Fenno, which clash with his own observations and interview data, and for which he provided an ad hoc explanation, may be misleading and the result of logrolling between the House and Senate conferees, combined with the fact that the House always makes its decisions prior to the Senate.

The data employed in this paper can be used to argue that the House is dominant in the conference. For example, we may consider the probability that a new start project gets accepted by the conference given that it is initiated by the House or the Senate. For 1967, 95 percent of the projects initiated by the House were put in the conference bill. For the same year, if the Senate initiated a project it had only a .70 percent change of being included in the budget. If the House, on the other hand, wished to cut a budget figure, it was successful with probability .85. Apparently the 
House was much the more potent body in 1967, yet the Senate success ratio for the year is .495-reflecting only slight House dominance.

By this measure the conference outcomes are generally dominated by the House, a pattern illustrated by the data in Table 1 .

\section{TABLE 1}

Proportion of New Starts Initiated by the House and Senate Which are Funded in the Conference Budget

\begin{tabular}{lcc}
\hline Year & $\begin{array}{c}\text { Proportion of } \\
\text { House New } \\
\text { Starts Funded }\end{array}$ & $\begin{array}{c}\text { Proportion. of } \\
\text { Senate New } \\
\text { Starts Funded }\end{array}$ \\
\hline 1951 & & 1.00 \\
1952 & 1.00 & .33 \\
1953 & & .64 \\
1954 & 1.00 & .58 \\
1955 & 1.00 & .91 \\
1956 & 1.00 & .91 \\
1957 & .98 & .65 \\
1958 & 1.00 & .79 \\
1959 & .96 & .63 \\
1960 & 1.00 & .72 \\
1961 & .94 & .77 \\
1962 & 1.00 & $-0-$ \\
1963 & .97 & .80 \\
1964 & .00 & .84 \\
1965 & 1.00 & .82 \\
1966 & .00 & .83 \\
1967 & .98 & .70 \\
\hline
\end{tabular}

* indicates that no new starts were initiated.

If the House adds a new start to the Corps' budget, then it is almost always funded in the final budget. A Senate-initiated new start usually has a much smaller chance of remaining in the conference budget. The House's superiority in the conference in obtaining new starts seems to stem from the fact that it is a bottleneck. House approval of a new project generally implies Senate approval but the converse is not the case.

How successful is the House in cutting the Corps' budget? Over the 17-year period from 1951 to 1967, the House has reduced budget requests on projects 452 times. The conference accepted a reduction either equal to the House figure, or, if the Senate made a resto- 
ration, closer to the House figure than to the Senate figure about 60 percent of the time. On the cursory analysis one must lean to the interpretation that not only is the House more successful than the Senate in getting its way on new starts, it is also fairly successful at reducing budget estimates on the projects in which it shows an interest.

A somewhat more precise impression can be obtained through estimating the parameters $(\mathrm{a}, \mathrm{b})$ in the model. Additionally, an estimate will be provided of the proportion (c) of Senate restorations of House cuts $\left(a D_{t}\right)$ which are accepted in the conference. The model estimated here is as follows: $S_{t}$ is the number of Senate revisions of House cuts and $C_{t}$ is the number of times the conference adopts a figure closer to the Senate figure than to that of the House on items which the House cut and the Senate restored. $P_{t}$ is the number of times the conference accepted a figure closer to the Senate than the House on items on which the Senate initiated an upward change. The following model was employed:

$$
\begin{aligned}
& \mathrm{S}_{\mathrm{t}}=\mathrm{aD}_{\mathrm{t}}+\varepsilon_{1} \\
& \mathrm{P}_{\mathrm{t}}=\mathrm{b} \mathrm{U}_{\mathrm{t}}^{\mathrm{S}}+\varepsilon_{2} \\
& \mathrm{C}_{\mathrm{t}}=\mathrm{cS}_{\mathrm{t}}+\varepsilon_{3}
\end{aligned}
$$

Regression estimates were obtained for these parameters and are given here:

$$
\begin{array}{ll}
\mathrm{a}=.77 & \mathrm{R}^{2}=.97 \\
\mathrm{~b}=.76 & \mathrm{R}^{2}=.86 \\
\mathrm{c}=.52 & \mathrm{R}^{2}=.82
\end{array}
$$

The Senate revises about 77 percent of the House cuts and the conference ends up closer to the Senate figure 52 percent of the time. However, the Senate allows House reductions to go unchallenged 23 percent of the time and this accounts for the phenomenon of 60 percent House success on the items on which it chooses to cut the budget estimate.

\section{Discussion}

The analysis of the previous section gives reason to believe that with respect to Corps of Engineers appropriations the House does somewhat better at getting what it wants in the conference than the 
Senate. It gets more of its suggested new starts and has some success at retaining the budget reductions it initiates. On the other hand, the Senate does manage to restore a majority of those Houseinitiated reductions which it chooses to contest. Apparently on these items of overlapping interest, both bodies are able to obtain what they want most of the time. The House is successful in reducing estimates on most of the projects that it cuts. The Senate is successful in raising funds on most of the projects that it restores.

These results should be interpreted within the context that, according to the traditional measure, there is a clear pattern of Senate victories. Of 1309 disagreements between the House and Senate over the period, the Senate prevailed on 859 items (65.5 percent). This figure is nearly identical to those computed by Fenno and Vogler. On the face of it, anyway, it would appear that the analysis carried out here may have some applicability to a reinterpretation of the findings of the other authors in this area.

At this point it is useful to provide some interview evidence that the model presented here corresponds to the images held by some participants in these conferences. ${ }^{9}$ One House conferee characterized the stance of the chairman of the House subcommittee:

Evins just gets what he want for the South. ... He is concerned about the Senate getting too many projects. He is a tough guy in the conference and I think we get what we want most of the time. Of course the Senate is not going to roll over and play dead. Those Senators are always there in the conference at least until the stuff in their states is taken care of. The will of the House is carried most of the time in the conference. . . This is because the Senate is spread out thinner. We get most of our members to the conference and they know something about the bill.

The same member went on to remark that Senator Ellender was the most powerful single member of the conferences but that his attention was focused on projects for Louisiana. He also pointed out that Senator Magnuson was usually present at conferences and was very successful at obtaining funding for projects in Washington ("Maggie's monuments").

A staff member of the Senate Appropriations Committee who has been involved in these conferences for many years was asked for his impressions of conference decision-making.

9 The interviews cited here were conducted by the author during the sessions of 1971 and 1972. 
Basically, the Senate agrees to the House on its new starts. They lose about half of our starts . . . the rest of the disagreements are just over money.

I asked him why the House doesn't concur on Senate projects.

Well, they try to hold down the budget over there. And, frankly, the Senate puts in some projects that we know are not going to get in the bill. But you know that the House cuts things just because they know that we are sitting over here and will restore a lot of that stuff.

Several other members of the House Subcommittee were interviewed (including the chief staff member) and there was essentially no disagreement on these points: the House and Senate are both interested in new starts but only the House has an interest in budget cutting. There was also general agreement that the House often did not concur with Senate requests for new projects and that the Senate was frequently successful in restoring House cuts.

The interview material provides good reason for caution in interpreting these findings as indications of House dominance in conference. Most of those spoken to were inclined to describe the process as fraught with strategic behavior. Those on the Senate side believed the House bill was usually "unreasonable" since the House Appropriations subcommittee is able to cut deeply, knowing that the Senate will frequently restore House reductions. In other words, on this interpretation the House may well want the Senate to succeed in restoring its reductions. Also, participants from both the House and Senate believed that the Senate frequently adds "too many" new starts. These beliefs on the part of participants must cast some doubt on whether the measures presented in studies of the conference can be unambiguously interpreted as measures of "who wins." Instead, the Conference Committee can more usefully be seen as an arena in which the two bodies try to attain partly incompatible goals. And to a certain extent both may be fairly successful.

The findings of this study seem to me to have some important consequences for the strategic behavior of interest groups. If one were to accept Fenno's and Volger's results at face value, groups desiring federal expenditures would be well-advised to concentrate their efforts on the Senate Appropriations subcommittees. My findings indicate a different strategy may be preferable. If an interest group wants to add a project to a bill, it should concentrate on the House subcommittee since a project added there will almost certainly survive the whole process. Paralleling this normative conclu- 
sion is the positive one that one ought to find a significant amount of lobbying to add projects taking place before the House subcommittee. Indeed, looking at the hearings for a ten-year period, there is fully as much lobbying activity before the House subcommittee as before the Senate subcommittee. ${ }^{10}$

${ }^{10}$ See John Ferejohn's Pork Barrel Politics (Stanford: Stanford Press, 1974). 